\title{
収縮性材料の乾燥応力
}

\author{
山口 信 吉* \\ Shinkichi YAMAGUCHI
}

Key Words: Shrinkage Material, Drying Stress, Viscoelastic Property, Hygroscopic Expansion ICoefficient

1.はじめに

水で練った粘土のような微粉体の層や多くの食品・ 木材類などは乾燥によって著しく収縮し，操作を誤る と乾燥割れを生ずることがある。そのような材料を本 稿では収縮性材料と呼ぶことにする。

ある種の含水高分子ゲルを電極ではさみ静電流を流 すと電気浸透的脱水が起りその体積は収縮する。電流 を切るとゲルは水を含んで可逆的に膨張するととより， そのゲルを人工筋肉として利用しようとする試みがあ る。その場合は脱水収縮を積極的に応用するあのであ るが，乾燥を目的とする場合は一般に材料の収縮およ びそれに伴うき裂の生成は好ましくない現象である。

乾燥割れ発生のメカニズムの追究には乾燥応力を推 測して検討するのが有効である。筆者は粘土の乾燥や 米粒の乾燥割れについての研究を行なっているが，本 稿ではその研究過程で得た知見に基づき，収縮性材料 の乾燥応力の問題点について概説する。

\section{2. 熱応力と乾燥応力}

乾燥応力は, 乾燥過程において材料内に形成される 不均一な含水率分布に起因する局所的な収縮量の差に よって誘発されるあのであり，それは，材料内の不均 一な温度分布に由来する熱応力と類似である。

乾燥は熱之物質の同時移動操作であり, 乾燥過程の 材料内部では温度と含水率がともに变化する。このた

昭和 62 年 3 月 9 日受付

*富山大学工学部化学工学科 (广 930 富山市五福 3190)

TEL 0764-41-1270

$$
\text { 〈著者紹介〉 }
$$

昭和 6 年石川県生れ 昭和 38 年静岡大学工短部工業化学科卒業 昭和39年静岡大学助手, 富山大学助手 昭和 58 年富山大学助教授, 現在に至る。 農学博士 (昭和58年筑波大学より授与される)
め, 乾燥応力として含水率差による応力のほかに熱応 力を考慮しなりればならないてとになる。しかし，通 常の乾燥操作における温度範囲では熱ひずみに比べて 含水率差によるひずみが标違いに大きく，一般に熱応 力は無視小となる。本稿では, 含水率差による応力= 乾燥応力, とおき, その乾燥応力の推定に熱応力解析 法を参照する。熱応力の解析には，まず材料内部の温 度分布の推定が必要であると同様に, 乾燥応力の解析 においては含水率分布の変化を求めなければならない。

一般に乾燥割れが問題之なる材料は比較的緻密であ り，その内部の水分は拡散則にしたがって移動すると みてよい。たとえば，比較的粗大な組織にみえる木材 では細胞腔内の毛管水(自由水と呼ぶこともある)の蒸 発期間はほとんど収縮せず，絨維飽和点以下の含水率 になると緻密な組織である細胞膜内の水分の移動によ って収縮が始まる。その紻維飽和点以下における水分 の移動は拡散現象として取扱われている ${ }^{233}$ 。

内部水分が拡散によって移動する場合, 含水率分布 の推定には拡散係数と平衡含水率の値が必要となる。 乙の場合, 拡散係数は含水率の関数となることが多く， また，木材のように水分移動の方向によって拡散係数 が異なることがあるから厄介である。平衡含水率は材 料のおかれた雾囲気の温度と湿度の関数となるが，そ の値は脱湿過程と吸湿過程では異なること（ヒステリ シス）が知られている。材料内部における水分の移動 は乾燥応力推定の基礎となる問題であるが, 同時に乾 燥研究に関する共通の問題でああるので，本稿では触 れないととにする゙。

急激な温度変化を受けるとガラス器具が割れるとい う現象は誰でも知っている。てれは普通，秒のオーダ

\footnotetext{
*乙の問題に関する報告 $2,23,26,30,39,41)$, 図書あるいは解説は多い が, たとえば，岡崎守男：化学工学，36，129(1972)や若林嘉 一郎：ケミカル・エンジニヤリング，11，13(1966) などを参 照されたい。
} 
一で起る現象であり，てのような急激な熱応力は熱衝 撃と呼ばれる。一方, 乾燥応力による割れは, 分から 時間のオーダーで起り，日や月のオーダーのとともあ る。乾燥応力推定に使用するために材料の機械的性質 を測定しようとするとき，そのようなタイムスケール に注意しなりればならない。

一般に材料はごく短い時間におりる応答では弾性的 挙動を示すが，時間が長くなるとその性質は非完全弾 性を呈するに至る。とくに含水率の高い材料の場合は その傾向が著しい。また，被乾燥材料には不均質なる のが多く，木材 ${ }^{199}$ や成型加工された粘土塊29)のように 非等方性材料もある。乙れらの理由により, 乾燥応力 の予測に必要な物性値の測定は困難であり, その困難 さがての分野の研究推進の妨げとなっている。

\section{3. 収縮特性}

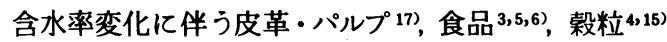
などの収縮量を測定し，収縮特性を定量的に表現しよ うとした試みがある。水で練った粘土塊の乾燥収縮量 は蒸発した水(液体)の体積に等しいととは古くより知

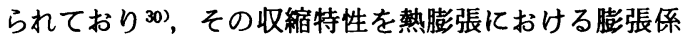
数に似た収縮係数として求めた研究がある ${ }^{16,17,29) 。 ~}$

木材は, 前述のように織維飽和点（その乾量基準含 水率は材料によって異なるが主に $0.25 \sim 0.30 \mathrm{~kg} / \mathrm{kg}$ ) 以下の含水率範囲で脱湿収縮または吸湿膨張(膨潤)す る。その範囲では含水率変化に伴う収縮と膨張は可逆 的であるが，著しい異方性を示す。いま，円柱状木材 の半径方向，接線方向および軸方向の線収縮率をそれ ぞれ $\alpha_{r}, \alpha_{t}$ および $\alpha_{z}$ とすると， $\alpha_{z}$ は他に比べてほぼ 一析小さく， $\alpha_{t}$ と $\alpha_{r}$ との間に大略 $\alpha_{t}=1.65 \alpha_{r}$ なる 関係がある ${ }^{19,23) 。}$

筆者らは，粘土層および玄米粒の含水率変化に伴う 体積变化を即定し，図1亿示す結果を得た ${ }^{39,40)}$ 。図の 縦軸は乾量基準の湿り比容積（みかけ容積－乾き質量） $v\left[\mathrm{~m}^{3} / \mathrm{kg}\right]$ であり，横軸は乾量基準含水率 $w[\mathrm{~kg} / \mathrm{kg}]$ である。てれらの結果に基づき, 熱膨張係数の定義に 照らして両試料の収縮・膨張の特性を考察する。

図 1 の○印は粘土層の测定值を表し、プロットは折 れ線 $\mathrm{ABC}$ で模型化される。区間 $\mathrm{AB}$ は勾配 $10^{-3} \mathrm{~m}^{3} /$ $\mathrm{kg}$ の直線で表され, 直線の $v$ 軸切片 Dは粘土粒子の比 容積 $v_{p}\left(=0.4 \times 10^{-3} \mathrm{~m}^{3} / \mathrm{kg}\right)$ となる。区間 $\mathrm{BC}$ では $v$ は $w$ の変化と無関係䎲一定値 $v_{b}$ を示す (この区間にお いても $v$ は $w$ にりわずかに变化するという報告 $16,17,29)$ がある)。液体水の比容積 $v_{w}$ が $1.0 \times 10^{-3} \mathrm{~m}^{3} / \mathrm{kg}$ であ ることより区間 $\mathrm{AB}$ では脱水量を液体水に換算した体

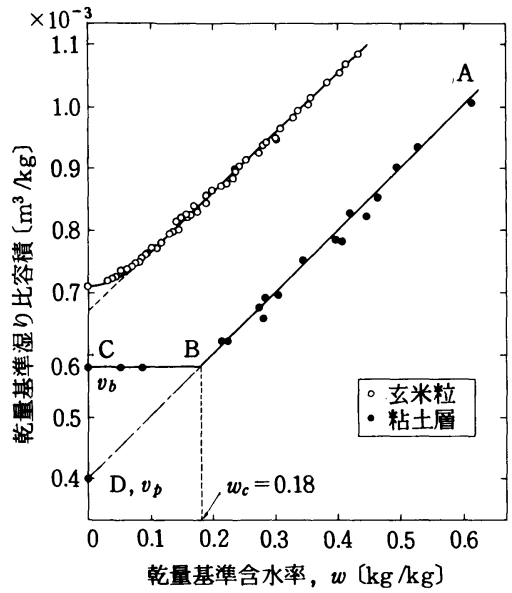

图1粘土首および玄米粒の収縮特性

積だけ層が収縮することが理解できる。B点の含水率 $w_{c}(=0.18 \mathrm{~kg} / \mathrm{kg})$ は乾燥速度曲線の限界含水率にほ ぼ一致する ${ }^{16,300}$ 。区間 AB における関係は次式で表さ れる。

$$
v=v_{p}+v_{w} w=v_{p}(1+r w)
$$

上式の $r=v_{w} / v_{p}$ は粘土粒子の比重 $(=2.5)$ である。

玄米の場合 (図 1 の印), $w=0.08$ 以上の範囲でプ ロットは直線で代表される。直線の勾配は $9.45 \times 10^{-4}$ $\mathrm{m}^{3} / \mathrm{kg}$ टなり，粘土層における勾配より小さい。乙れ は，失った水分 (液状水)に見合うだけ玄米粒は収縮し ないてと，すなわち，含水率低下に伴って玄米内部に 空隙部分が增えるととを意味する。他の穀粒について あ同様の傾向が見出されている ${ }^{40)}$ 。 $w<0.08$ の低含水 率ではプロットは直線からはずれ，一旦ての範囲にま で乾燥すると収縮之膨張の可逆性は失われる。

含水率範囲 $0.08<w<0.43$ 亿おいて玄米粒に関す る実験式は次のようになる。

$$
\begin{aligned}
v & =0.672 \times 10^{-3}+0.954 \times 10^{-3} w \\
& =v_{p}{ }^{\prime}(1+1.42 w)
\end{aligned}
$$

ここに， $v_{p}^{\prime}$ は上式で与えられる直線の $v$ 軸切片 $=0.672$ $\times 10^{-3} \mathrm{~m}^{3} / \mathrm{kg}$ である。

固体の熱膨張における線膨張係数 $\alpha_{T}$ および体膨張係 数 $\beta_{T}$ は，普通 $0{ }^{\circ} \mathrm{C}$ におりる長さ $l 0$ および体積 $V_{0}$ を 基準として次のように定義される ${ }^{31}$ 。

$$
\alpha_{T}=\frac{\mathrm{d}}{\mathrm{d} T}\left(\frac{l}{l_{0}}\right), \quad \beta_{T}=\frac{\mathrm{d}}{\mathrm{d} T}\left(\frac{V}{V_{0}}\right)
$$

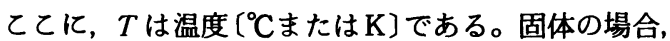
膨張が小さいので $l_{0}, V_{0}$ のかわりに任意の温度におけ る値を用いてあよく，等方性固体においては $\beta_{\tau}=3 \alpha_{T}$ とおける。 
乾燥収縮あるいは吸湿膨張において，基準含水率 $w_{s}$ 亿おりる長さを $l_{s}$, 体積をVsたおき，熱膨張にお けると同様に, 線膨張 (収縮) 係数

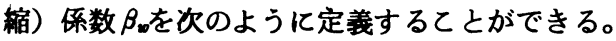

$$
\alpha_{w}=\frac{\mathrm{d}}{\mathrm{d} w}\left(\frac{l}{l_{\mathrm{s}}}\right), \quad \beta_{w}=\frac{\mathrm{d}}{\mathrm{d} w}\left(\frac{V}{V_{\mathrm{s}}}\right)
$$

ての場合の膨張は小さくないので, 熱膨張におりる近 似は許されない。すなわち，基準含水率値を定めると それを任意に変えるてとはできず，また等方性固体に おいても $\beta_{w}$ は $3 \alpha_{w}$ に一致しない。

図 1 亿示した粘土首および玄米粒子のように高含水 率域における $v$ 対 $w$ の関係が直線で表される場合，そ の直線範囲において式 (4) より次の関係が得られる。

$$
\frac{V}{V_{s}}=\frac{v}{v_{s}}=1+\beta_{w}\left(w-w_{s}\right)
$$

こてに，Vおよび vはそれぞれ含水率 $w$ におりる体積 および比容積であり，Vs および $v_{s}$ は基準含水率 $w_{s}$ に おりる値である。 $w_{s}$ の選び方は任意であり, $w_{s}=w_{c}$ と おいた報告 ${ }^{16,17,29)}$ その他 ${ }^{17)}$ がある。 $w_{s}=0$ とおくと， 上式の形は式 (1)のように単純となり，粘土層の場合， $v_{s}$ として粒子の物性值（此容積）的を使用できるという 便がある。式(1) と（5）とを比较すると，粘土首の体 膨張 (収縮) 係数 $\beta_{w}$ が粒子の真比重 $r$ に一致すること がわかる。

ここでは便宜上，基準含水率 $w_{s}=0$ と定め, 含水率 变化化伴う収縮と膨張に可逆性があるとみなして $\beta_{w}$ と $\alpha_{w}$ を水分膨張係数と呼ぶことにする。すると式(1) は

$$
v=v_{p}\left(1+\beta_{w} w\right)
$$

となり，玄米粒に関する式(2)においても $v_{p}=0.672 \times$ $10^{-3} \mathrm{~m}^{3} / \mathrm{kg}, \beta_{w}=1.42 \mathrm{~kg} / \mathrm{kg}$ とおけば，上式と同じ 形が得られる。

体積 $V$ は長さ $l$ の 3 乗に比例（比例定数C）する。

$$
V=C l^{3}, \quad \frac{V}{V_{s}}=\frac{v}{v_{s}}=\left(\frac{l}{l_{s}}\right)^{3}
$$

含水率変化に伴う収縮・膨張が等方性であれば，上式 と式 (4)より次の関係が導かれる。

$$
\beta_{w}=\frac{\mathrm{d}}{\mathrm{d} w}\left(\frac{l}{l_{\mathrm{s}}}\right)^{3}=3\left(\frac{l}{l_{\mathrm{s}}}\right)^{2} \frac{\mathrm{d}}{\mathrm{d} w}\left(\frac{l}{l_{\mathrm{s}}}\right)=3 \alpha_{w}\left(\frac{l}{l_{\mathrm{s}}}\right)^{2}
$$

$w_{s}=0$ とおき，そのときの比容積を $v_{p}$ ，長さを $l_{p}$ とす ると, $\left(l / l_{p}\right)^{3}=v / v_{p}$ であり, 式 (6) より次の関係が得 られる。

$$
\alpha_{w}=\frac{\beta_{w}}{3\left(1+\beta_{w} w\right)^{2 / 3}}
$$

一方, 線膨張係数 $\alpha_{v}$ を定数とみなすと, $l / l_{s}=\left(v / v_{s}\right)^{1 / 3}$ $=1+\alpha_{w} w$, と表され, 次の関係が得られる。

$$
\beta_{w}=3 \alpha_{w}\left(1+\alpha_{w} w\right)^{2}
$$

熱膨張です上の 2 式と同様な関係が成立するが，熱膨 張係数は一般に小さい $\left(10^{-5} \sim 10^{-6}\right.$ 程度)ので, $\beta_{T} t$ $\ll 1 ， \alpha_{T} t \ll 1$ となり， $\beta_{T}=3 \alpha_{T}$ と表せる。しかし, 含水率変化による収縮・膨張の場合，膨張係数が大き いため, 式(7)，（8）に示したように， $\beta_{w}$ と $\dot{\alpha_{w}}$ のど ちらかを定数とおくと，他は定数とならず $w$ の関数と なる。

応力解析において $\alpha_{w}$ を定数とおくと好都合である。 粘土層および玄米粒を等方性材料とみなして $\alpha_{w}$ を求 めてみた。 $v$ の実測値より $v^{1 / 3}$ を計算し，それと $w$ の 関係をプロットすると，含水率の高い範囲でプロット を一本の直線で結ぶてとができる。その直線の勾配よ り，粘土層および玄米粒の $\alpha_{w}$ をそれぞれ 0.51 および $0.39 \mathrm{~kg} / \mathrm{kg}$ と推定できた。

結局，等方性の粘土層の $\beta_{w}=2.5$ (乙のとき $\alpha_{w}$ は定 数でない), $\alpha_{w}=0.51$ (このとき $\beta_{w}$ は定数でない) と なる。玄米粒についても同様に $\beta_{w}=1.42, \alpha_{w}=0.39$ が求められたことになり，両試料とも $\beta_{w} \neq 3 \alpha_{w}$ とな るととがわかる。

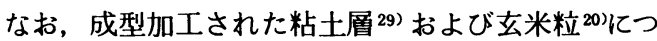
いて収縮の非等方性を認めた報告がある。

\section{4. 機械的性買}

極めて短時間に外力を加えると流体でも弾性を示す。 一方，固い水でできている水河は絶えず流れていて, 固体であ長い時間をかりると永久変形するととを示し ている ${ }^{13)}$ 。乙れらの現象より，材料の機械的性質は観

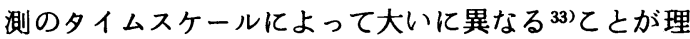
解できる。

前述のように，乾燥割れを生ずるまでの時間は短く ないので，その間の応力追究に使用する機械的性質の 测定においては，相応のタイムスケールを考慮しなり ればならない。通常の収縮性の被乾燥材料は非完全弾 性体であり，負荷に応じて永久変形が現れる。そのよ うな材料の性質は弾塑性あるいは粘弾性モデルで記述 される。温度と含水率一定の材料について考えると， 弾塑性モデルでは，完全弾性体と同様に応力はひずみ だけの関数となり，その応力・ひずみ関係に時間は全 く関与しない。乙れに対し粘弾性モデルでは，応力・ ひずみ関係が時間的に変化するのが特徽である。この 特徽の故に, 粘弾性モデルに基づく応力解析は複雑と なる。なお，乾燥過程では材料の温度と含水率が変化 するので, 乾燥応力解析に使用する機械的性質はそれ らの関数として測定すべきである。 


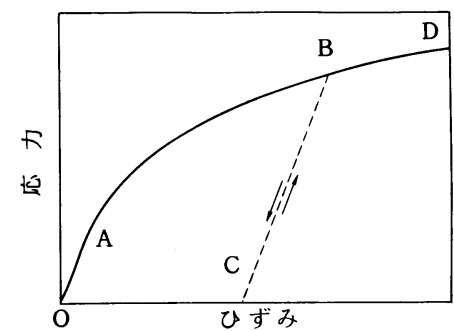

図 2 等変位速度の引張り試験におりる応力 ・ひずみ曲線の模型

通常, 固体の機械的性質の測定には単軸圧縮 ・ 引張 り試験, 曲げ試験あるいはねじり試験などが用いられ る。その他に, 粘弾性材料の短い夕イムスケールの特 性の測定法として, 試片に振動を与える動的測定法が 知られている33)。

被乾燥材料試片に対する定変位速度の引張り（圧縮 であよい）試験の結果は，たとえば図 2 の曲線のよう に得られることがある。ひずみの小さい区間 OA で応 力・ひずみ関係がほぼ直線となることより，その範囲 で材料を完全弾性体とみなした報告がある ${ }^{1,18,22) 。 ま ~}$ た，曲線の形が鋳鉄などの試験結果に似ているととよ り，その材料を硬化弾塑性体とみなしたものあある ${ }^{36)}$

こてで, 図 2 の曲線は等変位速度という極めて特殊 な条件下におりる試験結果であるととを強調しなけれ ばならない。図の区間 OAのように応力・ひずみ関係 が原点を通る直線になることは完全弾性体の備えるべ き必要条件であるが十分な条件ではない。すなわち， 相応のタイムスケールに扔いて, 異なる変位速度で除 荷と負荷を繰り返してあ, 同じ OA という軌跡をたど ることを確認しなければ，その材料を完全弾性体と断 定するてとはできない。また, 硬化弾塑性体の場合, 上記の OA に関する検討ののち, さらに硬化塑性を示 す区間 $\mathrm{AD}$ 上の任意の点 $\mathrm{B}$ において除荷と負荷を繰り 返し，図上の $\mathrm{B} \rightarrow \mathrm{C} \rightarrow \mathrm{B}$ の軌跡をたどることを確かめ なければならない。

鋳鉄や銅のような金属材料の性質は，たとえば人間 の寿命程度のタイムスケールで考えるならば，図 2 の ような結果よりその性質を硬化弾塑性体とみなしてあ よいであろう。しかし, 地球の歴史といった壮大な夕 イムスケールでは, あはやそのような理想化は許され ないに違いない。

粘土粒子の形状は板状のあのが多い34)。初めは粒子 がまったく無秩序に配列していて層の性質は等方性で あったとしても，その層に変位を与えると粒子配列に ある規則性が現れて非等方性を示すおそれがある。そ
のため，粘土層の機械的性質の測定には潜在的な難し さがあると予測される。

塑性の塑は，元来，土をてねて像などを作ることで

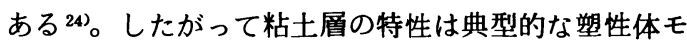
デルで表されるかといえばそうではない。円柱状の試 片に対してねじり試験を行なった詳しい実験によると， 水で練った粘土層の性質は粘弾性を呈する ${ }^{35)}$ 。また， 引張り試験の結果より, 粘土層の応力緩和係数（後述 のように粘弾性体の性質を表す量）を測定した報告む ある ${ }^{34)}$

てのように，粘土層でさえ粘弾性体とおけることよ り, 筆者は, 収縮性材料の力学モデルを弾性体や弾塑 性体とおくよりあ粘弾性体で表現するのが妥当と考え る。それを弾性体や弾塑性体で表現する場合，少なく とも, 粘弾性体の特徵である応力䋸和や遅延弾性の傾 向が相応のタイムスケールで無視できるかどうかを検 討すべきであろう。事実, 粘土層のほかにあ高分子材 料 ${ }^{8)}$ や食品・農産物 ${ }^{25)}$ な゙多くの材料の粘弾性が測定 されており，木材の曲げ試験の結果よりその粘弾性を 示した報告あある ${ }^{37}$ 。

固体の粘弾性は，粘性を表すダシュポットと弾性を 表すスプリングを組合せた力学模型で表覞するととが

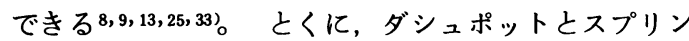
グを直列に配した模型を Maxwell 要素，並列に配し たあのを Kelvin(またはVoigt)要素と呼び, 前者は応 力緩和をうまく表現し, 後者は遅延弾性を表現する。

粘弾性材料に一定のひずみ $\varepsilon_{0}$ を与えておくと, 応力 $\sigma$ は時間 $t$ の経過ととあに変化(緩和) し $\sigma(t)$ と表さ れる。乙のときの応力とひずみの比 $\sigma(t) / \varepsilon_{0}$ を応力緩 和係数 (または緩和弾性率) $E(t)$ と呼ぶ。また, 材料 に一定の応力 $\sigma_{0}$ を負荷するとき，時間的に増大するひ ずみ $\varepsilon(t)$ と $\sigma_{0}$ との比 $\varepsilon(t) / \sigma_{0}$ をクリープコンプライ

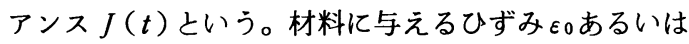
応力 $\sigma_{0}$ の大きさを変えても $E(t)$ あるいは $J(t)$ の値 に影響をおよぼさないとき，その材料を線形粘弾性体 という。

粘弾性材料の応力・ひずみ曲線には負荷速度の影響

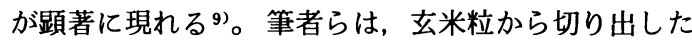
直径約 $1.5 \mathrm{~mm}$, 長さ $2 \mathrm{~mm}$ 強の円柱状試片を $1.7 \times$ $10^{-7} \sim 1.7 \times 10^{-4} \mathrm{~m} / \mathrm{s}$ の範囲で 6 水準 の定変位速度 で圧縮し，応力・ひずみ曲線が変位速度によって相互 に規則的にずれることを認めた。また，圧縮変位を一 定に保つとき，明らかに応力緩和現象を見出し，玄米 粒を 2 個の Maxw ell 要素からなる線形粘弾性体に近 似してその応力緩和係数を温度と含水率の関数として 


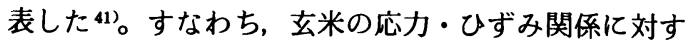
る時間・温度および含水率の依存性を示した。

多くの高分子材料の粘弾性に関する温度依存性之時 間依存性との間にある相関関係が見出されており，そ のような物質は熱レオロジー的に単純な材料と呼ばれ

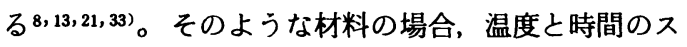
ケールには等価性があり, 温度の下降は時間スケール の拡大で，逆に，温度の上昇は時間スケールの縮小で 現象を同一化することができる ${ }^{21}$ 。収縮性の被乾燥材 料について便宜的に上記の温度・時間に含水率を加え て，それら 3 者のスケールに等価性を仮定しようとす

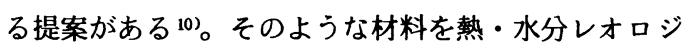
一的に単純な材料之呼ぶ。

筆者らは, 玄米粒を熱・水分レオロジー的に単純な 材料とみなすとととし, 応力緩和係数のマスター曲線 を求めた ${ }^{41}$ 。 マスター曲線とは, 基準の温度と含水率 における応力緩和係数と時間の関係を表す曲線であり， 任意の温度と含水率における応力緩和係数はある換算 係数 (時間 - 温度 - 含水率移動因子と呼ばれ, 温度と 含水率の関数となる）を乗じることにより, マスター 曲線に一致する。応力解析では, 刻々変化する温度と 含水率汇招ける応力緩和係数をマスター曲線に移し, マスター曲線を介して時間的に変化する応力を求める ことになる ${ }^{41}$ 。

粘弾性体の弾性率(すなわち応力緩和係数) は時間の 関数となるが, そのポアソン比もまた時間の関数とな る。線形粘弾性体の場合, 縦応力䋸和係数, せ九断応 力緩和係数およびポアソン比にそれぞれラプラス変換 をほどこすと, 変換された 3 者の間に比較的単純な関 係（それは完全弾性体において一定値を示す縦弾性率, せん断弾性率およびポアソン比の 3 者間の関係に類似

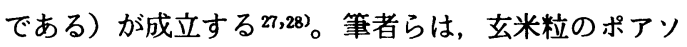
ン比を時間に無関係に不変と仮定して, 縱応力緩和係 数の実験値よりせん断応力緩和係数を推定した ${ }^{41)}$ 。

高分子材料の粘弾性の場合, 温度之時間のスケール の等価性には理論的根拠があるので, 温度の高い実験 によって粘弾性測定の時間を短縮することが可能であ る。乙れに対し, 収縮性材料の温度・含水率・時間の スケールの等価性は便宜的な仮定にすぎず，そてには 理論的根拠があるわけではない。したがって，たとえ ば含水率の高い試片を用いることにより測定時間の短 縮を計ることは危険であり, 材料の粘弾性測定には乾 燥所要時間のオーダーの時間を要する。その測定にお いては, 長時間におよぶ試験中, 試片の温度と含水率 が変化しないように工夫しなければならない。
一般に固体は圧縮負荷によるよりも引張り負荷によ って破壊されやすいので, 乾燥応力の正 (十) 值 (普通 引張り応力を正とする）が材料の引張り強度を越える とき割れが生ずると考えるのは自然である。しかるに， 固体の強度は外力の負荷速度によって異なるてとが知 られている ${ }^{38)}$ 。すなわち, タイムスケールが問題とな る。なお, 固体の破壊は本質的化率的現象であり， 強度の測定值にはばらつきが大きい12,38)。また, 荷重 をかけてから割れ目が発生するまでに時間のおくれが あり，そのおくれ時間のばらつきもまた大きい。乾燥 割れ機構の考察にあたり, 破壊という現象は顕著な時 間依存性を示す動的な現象であり，空間的のみならず

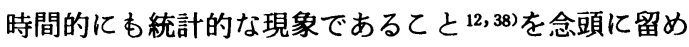
ておくとよい。

\section{5. 乾燥応力の推定}

応力解析では, 応力の平衡方程式, 変位・ひずみ関 係式および構成方程式（応力とひずみの関係を記述す る式を，適切な初期および境界条件のもとで解かな ければならない。粘弾性材料の場合, 構成方程式は履 歴積分を含む積分方程式となる。乙れに対し，完全弾 性体や弾塑性体は，応力・ひずみ関係に時間が一切関 与しない理想体であるため, 構成方程式に積分項を含 まない。

粘弾性論における応力楥和や塑性論における降伏条 件を展開する際には，実際の応力から静水王応力 $(\mathrm{Hy}$ drostatic stress : 立体座標系における 3 軸方向法線 応力の算術平均値）を減じ，その剩余の偏差応力を求 めるのが普通である。材料が等方性であれば, 静水圧 応力は材料に膨張 (Dilatation：収縮は負の膨張とみな す）を生じさせ, 偏差応力は形の変化(せん断変形)を

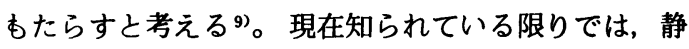
水圧だけでは固体に認めうるような永久変形を引き起 していない14)。乙の経験に基づいて粘弾性論では, 静 水圧応力による膨張を完全弾性的とみなし, 形状変化 に関わる偏差応力だけが応力緩和を呈するものと仮定 する9)。

解析が比較的容易な弾塑性モデルによる乾燥応力の 解析例は多く2,26,36)，なかには弾性モデルに基づくあ の 22) あある。様々な材料の粘弾性を測定した報告は枚 挙にいとまがないが，それを用いて乾燥応力を求めた 研究は少ない。わずかに，木材を等方性の粘弾性体之 みなし, 板材の両面から乾燥するときの応力を求めた 研究 ${ }^{37}$ が見られる。

線形粘弾性材料の内部に生じる熱応力について，温 
度と時間のスケールの等価性を組込んだ，すぐれた解

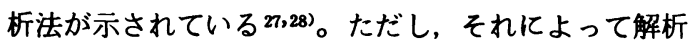
的に解が得られるのは特殊な条件下に限られる。乙の 方法に做って，温度・含水率・時間のスケールの等価 性を考慮した，乾燥応力解析法がある ${ }^{34) 。 し か し ， そ ~}$ の解析法には容認し難い理論の飛躍がある。

筆者らは上記の熱応力解析法27,28) を参照して乾燥過 程におりる玄米粒（均質な球状の線形粘弾性体と仮定） 内の乾燥応力の数值解法を提出し, それによって粒内 部応力を求めた (1)。その結果より，玄米粒の乾燥割れ に関するいくつかの特徴的傾向が合理的に説明される ことを示した。

\section{6. むすび}

玄米粒のように比較的緻密で変形し難いように見え

\section{引用 文 献}

1) Arora, V. K., S. M. Henderson and T. H. Burkhardt: Trans. ASAE, 16, 320 (1973)

2) Ashworth, J. C. : “Drying '80 (Proc 2nd Int. Drying Symp.)", 431 (1980)

3 ) Barron, L. F.: J. Fd Technol., 12, 73 (1977)

4) Bushuk, W. et al. : Cereal Chem., 37, 390 (1960)

$5)$ Chen, H. C. C.S. Chen : J. Agric. Engng . Res., 19, 97 (1944)

6) Earle, P. L. : Cereal Chem., 26, 267 (1949)

7 ) Ekstrom, G. A., J. B. Liljedahl and R. M. Peart : Trans. ASAE, 9, 556 (1966)

$8)$ Ferry, J. D. : "Viscoelastic Properties of Polymers (2nd Ed.)", John Wiley \& Sons, Inc. (1961)

9 ) Flügge, W. (堀幸夫訳) : “粘弾牲学”, 培風館(1973)

10) Hammerle, J. R. and N. N. Mohsenin : Trans. ASAE, 13, 372 (1970)

11) Henderson, S. M. : Rice J., 57, 16 (1954)

12）䏱素夫：応用物理, 36, 147 (1967)

13）井本立也：“概説レオロジー”，東京化学同人(1963)

14）Jaeger, J.C.（飯田汲事訳）：“弾性・破壊・流動論”, 共立出版 (1968)

15) Jones, C. R. and J. D. Cambell : Cereal Chem., 30, 177 (1953)

16）亀井三郎、水野成二, 塩見四郎：工業化学襍誌，38， 1074 (1935)

17）龟井三郎，桐栄良三：化学機械， 16，372 (1952)

18）川村登：農業機械学会誌， 12，43(1951)

19）北原覚一：“木材物理”，森北出版 (1967)

20)近藤万太郎, 岡村保: 農学研究, 19,143 (1932)

21）国尾武，M.L. Williams：日本機械学会誌，68，83 (1965)

22) Lee, K. : Ph. D. Thesis (Texas Univ.) (1972)
るあのであ応力緩和を呈する粘弾性体であるととを見 出し，また，粘土や小麦粉を水で練った塊の特性も粘 弾性モデルで表現できることを知り，筆者は，収縮性 の被乾燥材料は一般に粘弾性体とみなすべきではない かと考えるようになった。弾塑性論に基づく応力解析 法は比較的容易であるが，材料を弾塑性体と表すとき は乾燥に相応したタイムスケールでその性質を確認す べきであると重ねて主張したい。

本稿では, 乾燥応力の推定に用いる目的で収縮性材 料の物性値を測定する際の問題点に触れ, 乾燥応力解 析に関する概況を述べるに留めた。詳細については文 献などを参照していただきたい。視野のせまい筆者の 記述に偏見があるかあ知れないが，本稿がての分野の 進展に些かなりと役立てば幸いである。

23）満久蓠磨：“木材の乾燥”, 森北出版 (1962)

24）益田森治, 室田忠雄：“工業塑性力学”, 養養堂(1968)

25) Mohsenim, N. N. : "Physical Properties of Plant and Animal Materials, Vol.1", Gordon and Breach Sci. Pub. (1970)

26) Morgan, K., R. W. Lewis and H. R. Thomas : "Drying ' 80 (Proc. 2nd Int. Drying Symp.)”, 451 (1980)

27）牟岐鹿楼：日本機械学会誌, 64, 1392 (1961)

28) Muki, R. and E. Sternberg:Trans. ASME, Series $E, 28,2(1961-6), 193(1961)$

29）中山淳 : 旭硝子研究報告, 10，1（1960）

30) Newitt, D. M. and M. Coleman : Trans. Inst. Chem. Engrs, 30, 28 (1952)

31）日本機械学会編：“機械工学便覧”(第 4 版)，日本機械 学会(1960)

32）日本粘土学会編：“粘土ハンドブック”，技報堂(1967)

33）小野木重治：“レオロジー要論”, 楨書店 (1957)

34) Rao, V.N.M. and J.R. Hammerle : J. Agric.

Engng Res., 18, 253 (1973), 20, 283 (1975)

35）素木洋一：窯業協会誌，63，9 (1955)

36）穴戸郁郎, 丸山俊郎, 船木稔, 大谷茂盛 : 化学工学論 文集, 13, 78 (1987)

37）竹村富男：木材学会誌, 16, 108 (1970)；16, 115

(1970)； 18, 1 (1972)； 18, 105 (1972)

38) 寺尾宣三: “破壊の秘密”, 法政大学出版局 (1968)

39）若林喜一郎, 山口信吉, 松本利達, 三田哲郎 : 化学工 学論文集，3，189 (1977)

40）山口信吉, 若林嘉一郎, 細野八郎：農業機械学会誌, 39, 179 (1977)

41) 山口信吉, 山沢新吾, 若林嘉一郎: 農業機械学会誌, 43. 83 (1981)； 43, 239 (1981)； 43, 451 (1981); 43. $581(1982)$; 44, 61 (1982) 